\title{
BOMB RADIOCARBON IN TREE RINGS FROM NORTHERN NEW SOUTH WALES, AUSTRALIA: IMPLICATIONS FOR DENDROCHRONOLOGY, ATMOSPHERIC TRANSPORT, AND AIR-SEA EXCHANGE OF $\mathrm{CO}_{2}$
}

\author{
Quan Hua ${ }^{1,2} \bullet$ Mike Barbetti $^{3} \bullet$ Ugo Zoppi $^{1} \bullet$ David M Chapman $^{4} \cdot$ Bruce Thomson $^{3}$ \\ ABSTRACT. We have analyzed by radiocarbon 27 consecutive single rings, starting from AD 1952, of a preliminarily cross- \\ dated section (DFR 021) of Pinus radiata, which grew in Armidale, northern New South Wales, Australia. The bomb ${ }^{14} \mathrm{C}$ \\ results suggested the possibility of 2 false rings, and, consequently, 2 misidentified rings in the preliminary count for this sec- \\ tion. This possibility was supported by a better ring-width correlation between the revised DFR 021 count and other Pinus \\ radiata chronologies in the study region. This indicated that bomb ${ }^{14} \mathrm{C}$ is a useful tool to complement the standard techniques \\ of dendrochronology in tree species where annual rings are not always clearly defined.
}

Our accelerator mass spectrometry (AMS) ${ }^{14} \mathrm{C}$ results for Armidale Pinus radiata, on a corrected timescale, can be compared with previously published atmospheric and oceanic ${ }^{14} \mathrm{C}$ data. The data show interesting features of atmospheric circulation and the regional air-sea exchange of $\mathrm{CO}_{2}$ for the bomb period. On average, the difference between $\Delta^{14} \mathrm{C}$ values for Armidale $\left(30^{\circ} \mathrm{S}\right)$ and those for Tasmania $\left(42^{\circ} \mathrm{S}\right)$ was negligible, implying a small latitudinal ${ }^{14} \mathrm{C}$ gradient in the Southern Hemisphere. However, small offsets between Armidale and Tasmania were observed for some periods. The variation of these offsets suggests some slight changes in the relative contributions of the 2 excess ${ }^{14} \mathrm{C}$ sources (the northern troposphere and southern stratosphere) to the southern troposphere. In the decay of bomb ${ }^{14} \mathrm{C}$, atmospheric ${ }^{14} \mathrm{C}$ reached a global equilibrium at the end of the 1960s and decreased exponentially, halving every 16 years. The time for air-sea exchange of $\mathrm{CO}_{2}$ for southern Pacific mid-latitudes was found to be about $7.5 \mathrm{yr}$, which was equivalent to a $\mathrm{CO}_{2}$ flux from the atmosphere to the oceans of 21.5 moles $\mathrm{m}^{-2} \mathrm{y}^{-1}$ for the $1970 \mathrm{~s}$.

\section{INTRODUCTION}

Hundreds of nuclear weapons were detonated in the atmosphere between 1945 and 1980. The radiocarbon produced around the nuclear fire ball was directly injected into the atmosphere. As a result, the concentration of ${ }^{14} \mathrm{C}$ in the atmosphere increased dramatically in the late $1950 \mathrm{~s}$ and early $1960 \mathrm{~s}$. The atmospheric ${ }^{14} \mathrm{C}$ level reached a maximum in the Northern Hemisphere in $1963-1964$, almost double its pre-bomb level. Since then, the ${ }^{14} \mathrm{C}$ concentration in the atmosphere has been decreasing due to rapid exchange between the atmosphere and other carbon reservoirs (mainly the oceans and biosphere), and the absence of major atmospheric nuclear explosions.

Bomb ${ }^{14} \mathrm{C}$ was recognized as a useful tracer for the study of atmospheric circulation (Nydal and Lövseth 1983; Levin et al. 1985; Manning et al. 1990), air-sea exchange of $\mathrm{CO}_{2}$ (Nydal 1968; Druffel and Suess 1983), and the global carbon cycle (Oeschger et al. 1975; Broecker et al. 1980; Levin and Hesshaimer 2000). To contribute to the global effort, we have recently published the first long records of ${ }^{14} \mathrm{C}$ in tree rings from the northern tropics (Thailand, $19^{\circ} \mathrm{N}$ ) and the southern temperate region (Tasmania, Australia, $42^{\circ} \mathrm{S}$ ) for the bomb pulse period (Hua et al. 2000). Here we present the results of new measurements on a series of annual tree rings from Armidale, Australia $\left(30^{\circ} \mathrm{S}\right)$. This is the first time that a site in inland Australia has been used to examine the rise in atmospheric ${ }^{14} \mathrm{C}$ due to atmospheric nuclear explosions. The accelerator mass spectrometry (AMS) ${ }^{14} \mathrm{C}$ results were used to correct the preliminary ring boundary assignments in this cross-section, made first by using the standard techniques of dendrochronology. We then discuss the features of bomb ${ }^{14} \mathrm{C}$ in the Southern Hemisphere and their implications for atmospheric transport. Finally, we esti-

\footnotetext{
${ }^{1}$ Australian Nuclear Science and Technology Organisation (ANSTO), PMB 1, Menai, New South Wales 2234, Australia.

${ }^{2}$ Corresponding author. Email: qhx@ansto.gov.au.

${ }^{3}$ The NWG Macintosh Centre for Quaternary Dating, Madsen Building F09, University of Sydney, New South Wales 2006, Australia.

${ }^{4}$ School of Geosciences, Madsen Building F09, University of Sydney, New South Wales 2006, Australia.
} 
mate the air-sea exchange of $\mathrm{CO}_{2}$ for southern Pacific mid-latitudes, based on our measured ${ }^{14} \mathrm{C}$ data from Armidale tree rings and those from Great Barrier Reef corals for the bomb period reported by Druffel and Griffin (1995).

\section{SAMPLE DESCRIPTION}

An introduced species of pine in Australia, Pinus radiata, was used for this study. The tree was on the New England Tableland of northern New South Wales, Australia $\left(30^{\circ} \mathrm{S}, 152^{\circ} \mathrm{E}\right)$. This mediumsized tree, catalog nr DFR 021, grew near a fence along a quiet countryside road from Armidale to Dangar Falls. The sampling site is at moderate altitude, about $1000 \mathrm{~m}$ above sea level and about 5 $\mathrm{km}$ east-southeast of Armidale. The tree was a sapling in 1922 and was felled in mid-winter (July) 1998, when the 1997 ring was complete but the 1998 ring had not yet begun to form. We chose DFR 021 over sections from neighboring trees because the rings were wider and easier to sample for ${ }^{14} \mathrm{C}$ analysis. The cross-section used for ${ }^{14} \mathrm{C}$ analysis is shown in Figure 1. The heartwood-sapwood transition for DFR 021 is around rings 1962-1966. Note that organic materials (e.g., lignin, waxes) in the outermost sapwood rings may be added to heartwood at the time of conversion from sapwood to heartwood (Cain and Suess 1976), but should be removed by pretreatment to pure cellulose (Hua et al. 1999 and references therein). This pretreatment was employed for this study (see below), so that the ${ }^{14} \mathrm{C}$ measurements are unaffected. The outer rings, where samples were taken for ${ }^{14} \mathrm{C}$ measurement, are typically $2-3 \mathrm{~mm}$ wide, necessitating the use of AMS for ${ }^{14} \mathrm{C}$ analysis. During the summer growing season of Armidale Pinus radiata, the air mass movement is predominantly from the northeast/southeast sector (Linacre and Geerts 1997).

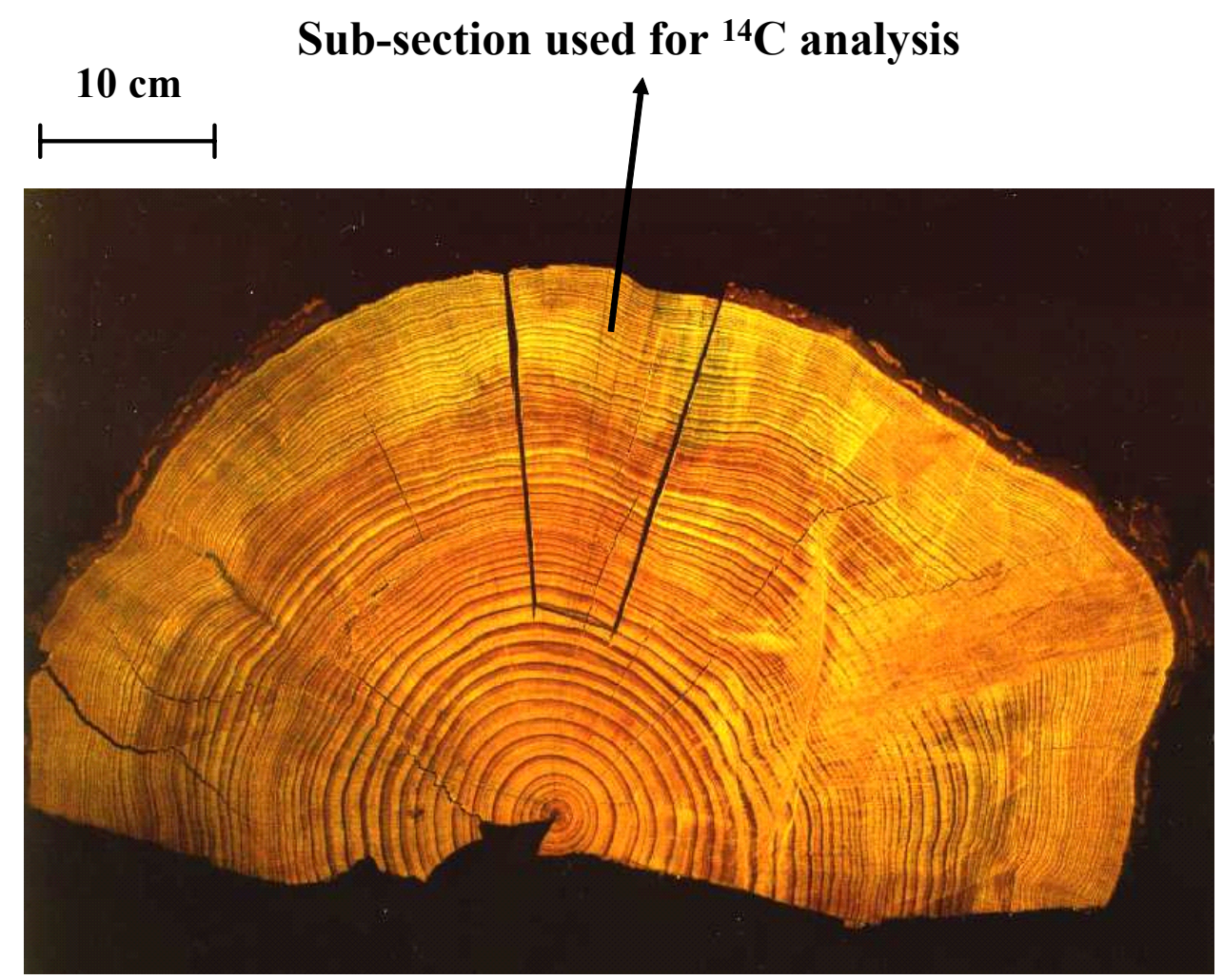

Figure 1 Cross-section of Armidale Pinus radiata DFR 021 with rings from AD 1922 to 1997, from which a subsection was used for AMS ${ }^{14} \mathrm{C}$ analysis. 


\section{AMS ${ }^{14} \mathrm{C}$ ANALYSIS AND THE DENDROCHRONOLOGY OF PINUS RADIATA}

The ring pattern of Pinus radiata is clear and well-defined for the inner part of the DFR 021 section, where the rings are wide. For this part of the section, a typical ring width is $5-10 \mathrm{~mm}$. As the tree became older and the outer rings became narrower, the ring pattern was less clear, with many doubtful ring boundaries. There are many bands of small dark cells, which are similar to ring boundaries, across the section. This made it difficult to date the DFR 021 section using the standard techniques of dendrochronology because these uncertain ring boundaries might result in false (or intra-annual) rings being counted in one part of the section and true rings not being counted in other parts of the section or vice versa. The cross-dating of DFR 021 against other Pinus radiata trees in the region was carried out at the NWG Macintosh Centre for Quaternary Dating of the University of Sydney and a preliminary ring count (pc) for DFR 021 was achieved.

Fortunately, the narrow rings in the section, where the potential problems occur, are in the bomb pulse period. There are 2 unique features of bomb ${ }^{14} \mathrm{C}$, which can be used to examine the preliminary chronology of DFR 021 . The first one is that atmospheric ${ }^{14} \mathrm{C}$ contents are similar for similar latitudes in the Southern Hemisphere. We employed atmospheric ${ }^{14} \mathrm{C}$ records for Pretoria $26^{\circ} \mathrm{S}$ (South Africa, Vogel and Marais 1971) and Wellington $41^{\circ} \mathrm{S}$ (New Zealand, Manning and Melhuish 1994) as a norm for the ${ }^{14} \mathrm{C}$ level for Armidale. The second feature is the significant difference in ${ }^{14} \mathrm{C}$ levels between consecutive annual tree rings during the bomb period, especially for the period of rising atmospheric ${ }^{14} \mathrm{C}$ and a decade after the major bomb peak (1955-1965 and 1966 to the late 1970s). These features are very effective for detecting misidentified rings.

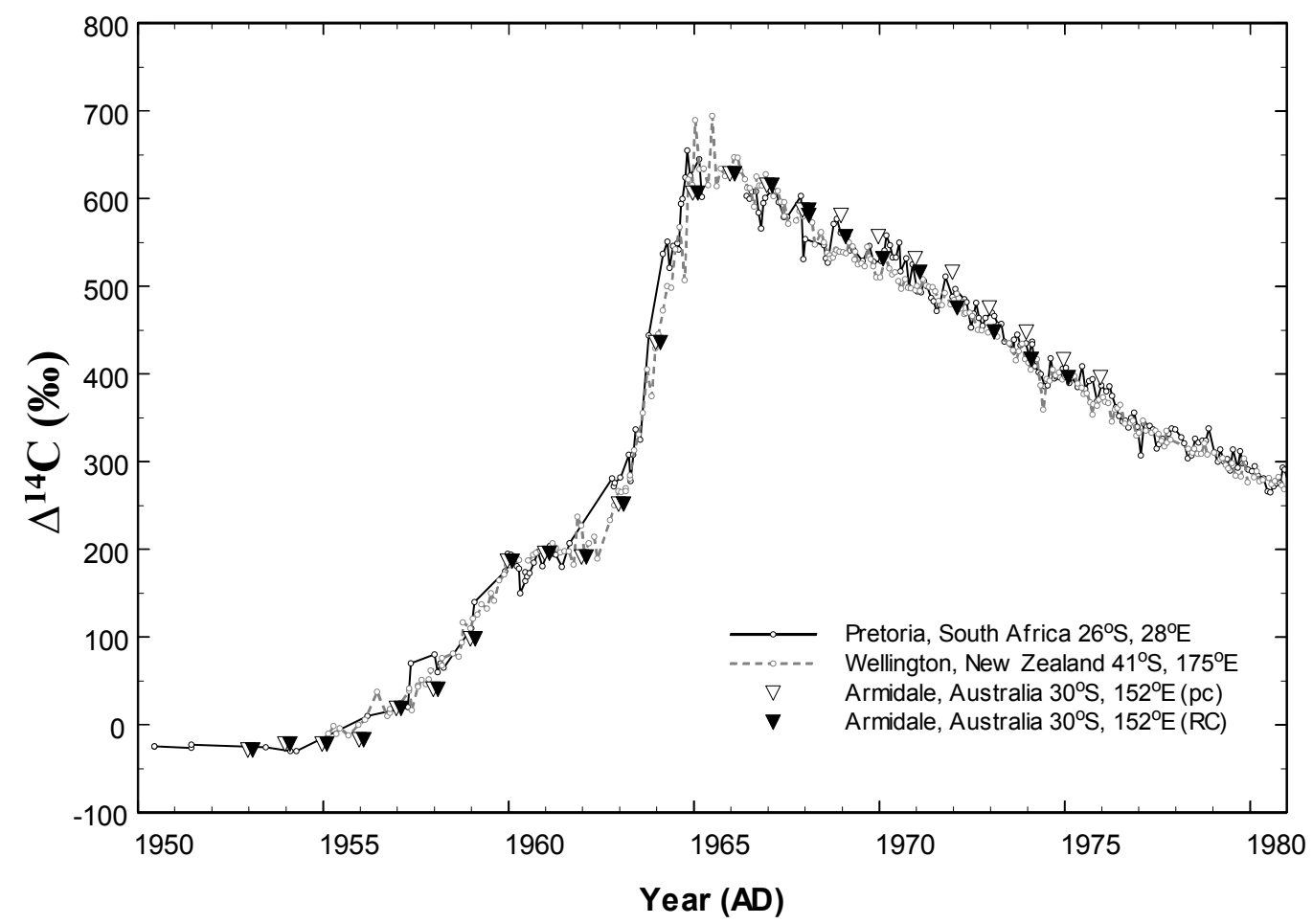

Figure $2{ }^{14} \mathrm{C}$ in tree rings versus atmospheric ${ }^{14} \mathrm{CO}_{2}$ at similar latitudes. Lines represent $\Delta^{14} \mathrm{C}$ values for atmospheric samples. Data for Pretoria and Wellington are from Vogel and Marais (1971) and Manning and Melhuish (1994), respectively. Triangles depict $\Delta{ }^{14} \mathrm{C}$ values for tree rings. $\Delta^{14} \mathrm{C}$ values for Armidale Pinus radiata are shown for the preliminary ring counts (pc) and revised chronology (RC). 
Twenty-four consecutive single tree ring samples, starting from AD 1952, were prepared for AMS ${ }^{14} \mathrm{C}$ analysis using the protocols set up by Hua et al. (1999). Our sampling strategy was to avoid the ring boundary areas due to very different levels of ${ }^{14} \mathrm{C}$ between consecutive rings. The woody material of each ring, well clear from ring boundaries, was selected for ${ }^{14} \mathrm{C}$ analysis. The samples were pretreated to alpha-cellulose using the method of Hua et al. (2000). The pretreated material was converted to graphite using methods described in Hua et al. (2001). The AMS ${ }^{14} \mathrm{C}$ measurements were performed using the ANTARES facility at ANSTO (Lawson et al. 2000; Fink et al. 2003), with a precision of $0.35-0.45 \%$.

The AMS ${ }^{14} \mathrm{C}$ results for DFR 021 were reported in $\Delta{ }^{14} \mathrm{C}$ values, after corrections for isotopic fractionation using $\delta^{13} \mathrm{C}$ and radioactive decay of both sample and standard (Hua et al. 1999, and the $\Delta$ term of Stuiver and Polach 1977). The results are presented in Table 1 and illustrated in Figure 2. The $\Delta^{14} \mathrm{C}$ values for tree rings are plotted as points in the middle of the presumed growing period of December-January. For ease of comparison, the atmospheric ${ }^{14} \mathrm{C}$ records from the Southern Hemisphere temperate regions, namely Pretoria $26^{\circ} \mathrm{S}$ (South Africa) and Wellington $41^{\circ} \mathrm{S}$ (New Zealand), are also shown in Figure 2.

Table 1 Measured $\Delta^{14} \mathrm{C}$ from Pinus radiata in Armidale, Australia $\left(30^{\circ} \mathrm{S}, 152^{\circ} \mathrm{E}\right)$, for both preliminary ring counts and revised chronology.

\begin{tabular}{llllr}
\hline & & \multicolumn{2}{c}{ Ring formation (year AD) } & \\
\cline { 2 - 4 } $\begin{array}{llll}\text { Laboratory } \\
\text { code }\end{array}$ & $\delta^{13} \mathrm{C}$ & $\begin{array}{l}\text { Preliminary } \\
\text { ring counts }(\mathrm{pc})\end{array}$ & $\begin{array}{l}\text { Revised } \\
\text { chronology }(\mathrm{RC})\end{array}$ & $\Delta^{14} \mathrm{C}(\%)$ \\
\hline OZE208 & -22.1 & 1952 & 1952 & $-28.8 \pm 4.5$ \\
OZE209 & -21.9 & 1953 & 1953 & $-21.8 \pm 4.1$ \\
OZE210 & -21.5 & 1954 & 1954 & $-22.0 \pm 4.3$ \\
OZE211 & -22.6 & 1955 & 1955 & $-17.0 \pm 4.6$ \\
OZE212 & -22.4 & 1956 & 1956 & $18.7 \pm 4.5$ \\
OZE213 & -19.9 & 1957 & 1957 & $40.5 \pm 3.3$ \\
OZE214 & -21.0 & 1958 & 1958 & $98.1 \pm 4.2$ \\
OZE215 & -21.8 & 1959 & 1959 & $186.8 \pm 4.2$ \\
OZE216 & -20.4 & 1960 & 1960 & $195.5 \pm 3.4$ \\
OZE217 & -22.3 & 1961 & 1961 & $191.2 \pm 4.1$ \\
OZE218 & -22.9 & 1962 & 1962 & $251.6 \pm 4.6$ \\
OZE219 & -22.1 & 1963 & 1963 & $435.8 \pm 5.2$ \\
OZE220 & -21.8 & 1964 & 1964 & $606.6 \pm 5.9$ \\
OZE221 & -20.7 & 1965 & 1965 & $628.2 \pm 5.7$ \\
OZE222 & -20.5 & 1966 & 1966 & $615.4 \pm 5.6$ \\
OZE223 & -21.9 & 1967 & 1967 (early wood) & $586.9 \pm 5.4$ \\
OZE224 & -21.9 & 1968 & 1967 (late wood) & $580.7 \pm 5.3$ \\
OZE225 & -21.1 & 1969 & 1967 & $583.8 \pm 3.9$ \\
OZE226 & -21.7 & 1970 & 1968 & $556.6 \pm 5.6$ \\
OZE227 & -22.7 & 1971 & 1969 & $531.6 \pm 5.7$ \\
OZE228 & -23.0 & 1972 & 1970 & $516.1 \pm 5.1$ \\
OZE229 & -22.2 & 1973 & 1971 & $475.6 \pm 6.0$ \\
OZE230 & -22.3 & 1974 & 1972 & $448.1 \pm 5.3$ \\
OZE231 & -21.8 & 1975 & 1973 & $416.7 \pm 5.4$ \\
OZG572 & -22.9 & 1976 & 1974 & $396.0 \pm 5.6$ \\
OZG573 & -22.5 & 1977 & 1975 & $378.7 \pm 4.4$ \\
OZG574 & -23.4 & 1978 & 1976 (early wood) & $351.9 \pm 4.9$ \\
& & & 1976 (late wood) & $340.5 \pm 4.9$ \\
\hline & & & 1976 & $346.2 \pm 5.2$ \\
\hline
\end{tabular}


Excellent agreement between measured ${ }^{14} \mathrm{C}$ data for Armidale tree rings and atmospheric ${ }^{14} \mathrm{C}$ records for Pretoria for the period of 1952 to 1967 (pc) was found. However, for the period of 1968 to 1975 (pc), $\Delta^{14} \mathrm{C}$ values for the Armidale tree rings were significantly higher than those of atmospheric ${ }^{14} \mathrm{C}$ records for Pretoria and Wellington. In addition, $\Delta{ }^{14} \mathrm{C}$ value for ring $1967(\mathrm{pc})$ was equal to that for ring 1968 (pc) (Table 1). These results suggested that 1967 (pc) ring boundary was a false one and that rings 1967 and 1968 (pc) were in fact a single 1967 ring.

To test this hypothesis, we shifted results one year back for rings 1968-1975 (pc) and plotted their $\Delta{ }^{14} \mathrm{C}$ values in Figure 2. A very good agreement with the atmospheric data sets was then found, indicating that the hypothesis was correct. We therefore adopted a revised ring count, with the (new) 1967 ring consisting of the 2 rings, 1967 and 1968 of the preliminary count (Figure 3). We then noted the similarity between rings 1967-1968 (pc) and rings 1977-1978 (pc) (see Figure 3), and inferred that the 1977 (pc) ring boundary may also be a false one. To confirm this, the 3 single rings, 1976-1978 (pc), were prepared and measured by AMS. The ${ }^{14} \mathrm{C}$ results from these rings, which are also presented in Table 1, showed that the $\Delta^{14} \mathrm{C}$ value for ring $1977(\mathrm{pc})$ was similar to that for ring 1978 (pc). These results confirmed that the 1977 (pc) ring boundary was also a false one.

Table 2 Ring-width correlation between DFR 021 and other Pinus radiata trees in the study region. Calculation was performed for 25-yr segments lagged 12 yr.

\begin{tabular}{lll}
\hline & \multicolumn{2}{c}{ Statistical correlation } \\
\cline { 2 - 3 } $\begin{array}{l}\text { Counted segment } \\
\text { (year AD) }\end{array}$ & Preliminary ring counts $(\mathrm{pc})$ & Revised chronology $(\mathrm{RC})$ \\
\hline $1923-1947$ & 0.79 & 0.79 \\
$1935-1959$ & 0.82 & 0.82 \\
$1947-1971$ & 0.79 & 0.83 \\
$1959-1983$ & 0.54 & 0.69 \\
$1971-1995$ & 0.52 & 0.63 \\
$1973-1997$ & 0.53 & 0.65 \\
\hline
\end{tabular}

${ }^{14} \mathrm{C}$ contents for rings $1952-1976$ of the revised count (rc), equivalent to rings $1952-1978$ (pc), agreed well with the atmospheric records for Pretoria and Wellington. This therefore meant that 2 later true rings were not counted, somewhere between rings 1979 and 1997 (pc). Using the standard techniques of dendrochronology, and the fact that ring 1982 in other trees from this site was a very narrow ring influenced by a strong El Niño event (low rainfall from November 1982 to January 1983 for the Armidale region, data files provided by Bureau of Meteorology 1999), we inferred that the correct ring boundaries were those shown in the revised count (Figure 3). Unfortunately, we could not use additional ${ }^{14} \mathrm{C}$ measurements to confirm the revised count because the ${ }^{14} \mathrm{C}$ levels between consecutive rings in this period are not so different (the atmospheric ${ }^{14} \mathrm{C}$ bomb curves for the Southern Hemisphere from 1980 onwards decreases less steeply; Vogel and Marais 1971; Manning and Melhuish 1994). However, after the identification of 2 false ring boundaries in 1967 and 1976 (rc), and new ring boundaries for 1982 and 1991 (rc), the revised count was supported by statistical correlation, with a significant improvement in ring-width correlation between DFR 021 and other Pinus radiata trees in the region for rings 1947 outwards (Table 2). This gave us confidence in the revised chronology (RC). 


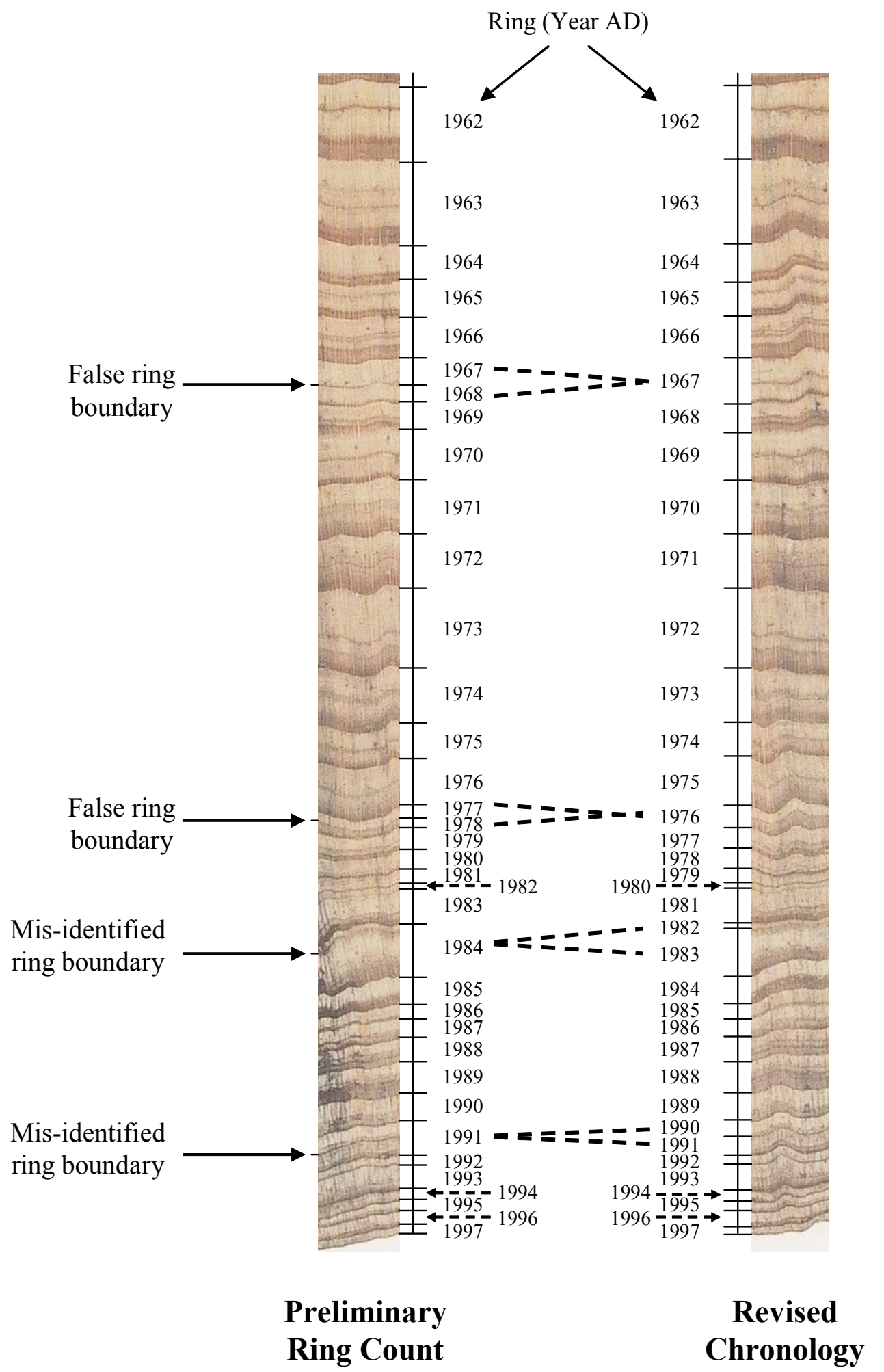

Figure 3 Tree-ring pattern of Armidale Pinus radiata DFR 021. Preliminary ring counts (pc) versus revised chronology (RC). 


\section{IMPLICATIONS FOR ATMOSPHERIC TRANSPORT}

Measured $\Delta^{14} \mathrm{C}$ values for Armidale Pinus radiata (RC only) are shown in Figure 4, together with previously published $\Delta^{14} \mathrm{C}$ data for tree rings at different latitudes from the Northern and Southern Hemisphere. They are, respectively, the data for Hungary $\left(48^{\circ} \mathrm{N}, 1951-1978\right.$, Hertelendi and Csongor 1982), Germany ( $49^{\circ} \mathrm{N}, 1966-1982$, Levin et al. 1985), Japan (38 $\mathrm{N}, 1960-1969$, Muraki et al. 1998), Thailand ( $19^{\circ} \mathrm{N}, 1952-1975$, Hua et al. 2000), and Tasmania (Australia, $42^{\circ} \mathrm{S}, 1952-1975$, Hua et al. 2000). These data are plotted in the middle of the growing period: June-July for the Northern Hemisphere and December-January for the Southern Hemisphere.

The difference between Armidale $\left(30^{\circ} \mathrm{S}\right)$ and Tasmania $\left(42^{\circ} \mathrm{S}\right)$ was generally small or negligible (Figure 4). The weighted average of the difference of the 2 data sets for the period influenced by atmospheric nuclear detonations (rings 1954-1975) was $0.3 \pm 2.9 \%$ (Armidale is higher). The magnitude of this difference is similar to the mean monthly difference of $0.5 \pm 1.1 \%$ between Pretoria $\left(26^{\circ} \mathrm{S}\right)$ and Wellington $\left(41^{\circ} \mathrm{S}\right)$ for the period of $1957-1993$ (Hua and Barbetti 2003). This indicated a small latitudinal gradient in terms of $\Delta^{14} \mathrm{C}$ for the Southern Hemisphere. The reason for the low latitudinal gradient in the Southern Hemisphere is that the sources of bomb ${ }^{14} \mathrm{C}$, which are mainly in the Northern Hemisphere, are far from the south (Manning et al. 1990), and once the ${ }^{14} \mathrm{C}$ excess is transported over the broad Inter-Tropical Convergence Zone (ITCZ), atmospheric ${ }^{14} \mathrm{C}$ diffuses rapidly with fast mixing in the Southern Hemisphere and does not allow for a large gradient there (Hua et al. 1999). This feature of bomb ${ }^{14} \mathrm{C}$ in the Southern Hemisphere is in contrast to that for the Northern Hemisphere, where there is a large latitudinal gradient of $\Delta^{14} \mathrm{C}$ - note the significant difference between $\Delta^{14} \mathrm{C}$ values for Hungary $\left(48^{\circ} \mathrm{N}\right)$ and those for Japan $\left(38^{\circ} \mathrm{N}\right)$ at least for the bomb peak period (Figure 4).

Although the average difference between Armidale and Tasmania was negligible, small offsets between the 2 data sets were observed during the rise and fall of bomb ${ }^{14} \mathrm{C}$. Note that the excess ${ }^{14} \mathrm{C}$ produced by bomb tests was mostly injected into the stratosphere, then returned to the troposphere through the mid- to high-latitude tropopause gap in both hemispheres during the spring and summer time of each hemisphere. Because the main sources of bomb ${ }^{14} \mathrm{C}$ were in the Northern Hemisphere, the southern troposphere received excess ${ }^{14} \mathrm{C}$ from the northern troposphere and the northern stratosphere through the southern stratosphere. Excess ${ }^{14} \mathrm{C}$ from the northern troposphere reached Armidale $\left(30^{\circ} \mathrm{S}\right)$ before it reached Tasmania $\left(42^{\circ} \mathrm{S}\right)$, meanwhile Tasmania was more sensitive to the injection from the southern stratosphere (compared to Armidale) because Tasmania is located further south and is close to the injection areas (mid- to high-latitudes) in the Southern Hemisphere. ${ }^{1}$ Due to a very similar growing season between Armidale Pinus radiata and Tasmanian Huon pine (approximately from November to February), the variation of the small offsets between Armidale and Tasmania during the bomb period might indicate some indications about relative contributions of the 2 excess ${ }^{14} \mathrm{C}$ sources to the southern troposphere.

\footnotetext{
${ }^{1}$ The seasonal structure for the Wellington record $\left(41^{\circ} \mathrm{S}\right.$, New Zealand), which is close to Tasmania in latitude, was well determined with a maximum in March and a minimum in August (until 1980; Manning et al. 1990). This seasonality reflected the injection of excess ${ }^{14} \mathrm{C}$ from the southern stratosphere into the southern troposphere. Meanwhile, the seasonal structure for the South Pacific sites including Funafuti $9^{\circ} \mathrm{S}$ (Tuvalu) and Suva $18^{\circ} \mathrm{S}$ (Fiji), which is close to Armidale in latitude, were not well determined (Manning et al. 1990). It is likely that these sites received more excess ${ }^{14} \mathrm{C}$ from the Northern Hemisphere, which became diffused when transferred to the Southern Hemisphere across the broad ITCZ. As a result, atmospheric ${ }^{14} \mathrm{C}$ over these sites lost the Northern Hemisphere seasonal pattern: maximum in July-August and minimum in January-March (Meijer et al. 1995), which mainly reflected the seasonality of the injection of excess ${ }^{14} \mathrm{C}$ from the northern stratosphere to the northern troposphere.
} 


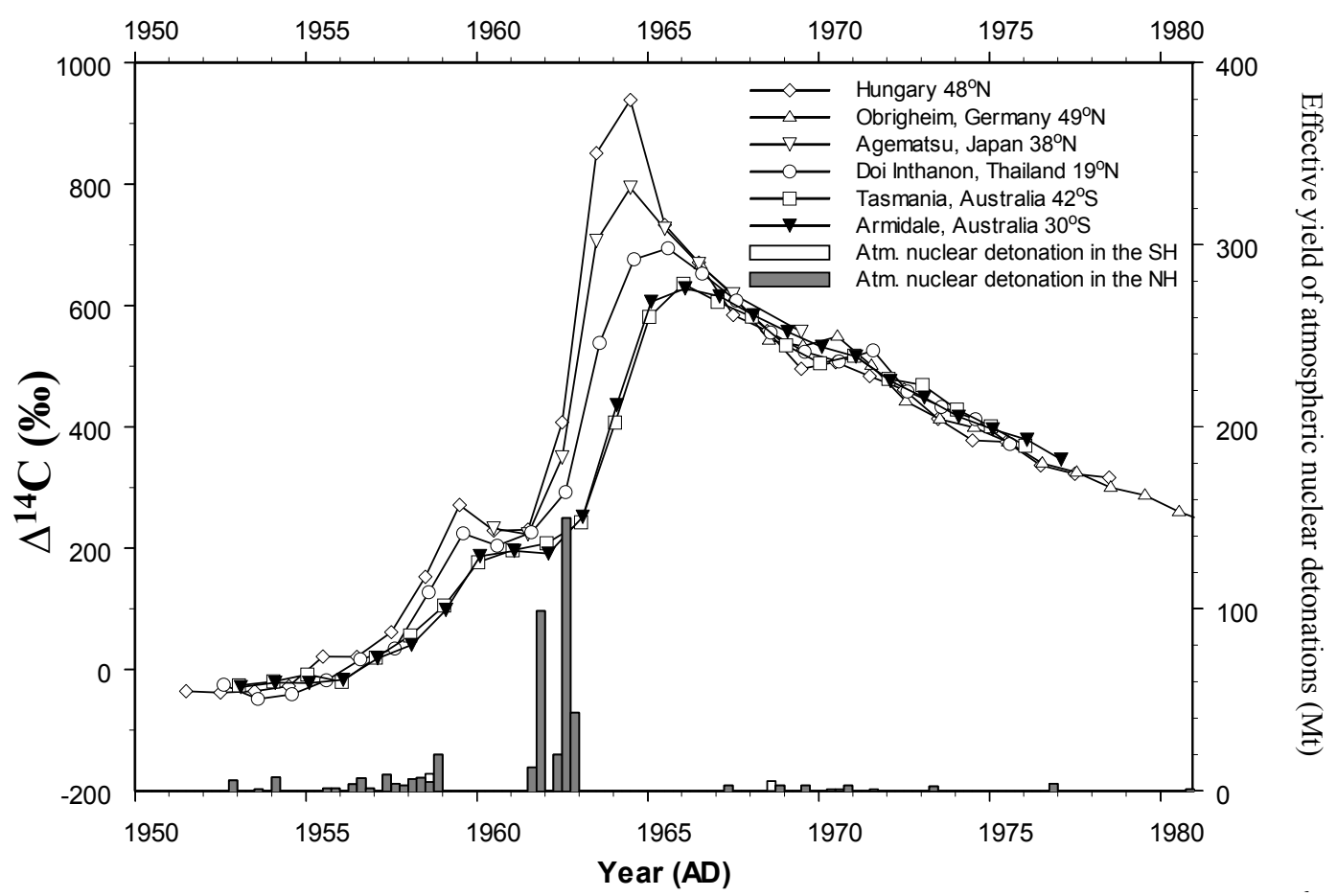

Figure $4{ }^{14} \mathrm{C}$ in tree rings at different latitudes and atmospheric nuclear detonations AD 1950-1980. Symbols depict $\Delta^{14} \mathrm{C}$ values for tree rings. Data sources are Hertelendi and Csongor (1982) for Hungary, Levin et al. (1985) for Germany, Muraki et al. (1998) for Japan, and Hua et al. (2000) for Thailand and Tasmania. Measured $\Delta^{14} \mathrm{C}$ values for Armidale Pinus radiata are shown for the revised chronology (RC) only. Error bars are too small to be shown. Bars represent effective yield of atmospheric nuclear detonations for 3-month periods (for 1945-1976, Enting 1982; for 1977-1980, Yang et al. 2000).

$\Delta^{14} \mathrm{C}$ values for Armidale were slightly lower than those for Tasmania at the ends of 1954, 1957, and 1961 (Figure 4). Unfortunately, the 2 atmospheric ${ }^{14} \mathrm{C}$ records for Pretoria and Wellington shown in Figure 2, which have latitudes similar to Armidale and Tasmania, respectively, are not detailed enough at those times to determine if there are similar ${ }^{14} \mathrm{C}$ offsets between the 2 records. It is interesting that the ends of 1957 and 1961 were times when there were changes in the rates of increase of ${ }^{14} \mathrm{C}$ in Armidale Pinus radiata: a small rise from the end of 1955 to the end of 1957, an intermediate increase from the end of 1957 to the end of 1959, a plateau from the end of 1959 to the end of 1961, and a steep rise from the end of 1961 to the end of 1965 (Figure 4). These changes suggest variations in the amount of excess ${ }^{14} \mathrm{C}$ transferred from the northern troposphere to the southern troposphere. There was a plateau in $\Delta^{14} \mathrm{C}$ in the northern troposphere during 1956 , followed by a small increase during 1957. There was effectively no increase in the amount of ${ }^{14} \mathrm{C}$ transferred to the Southern Hemisphere during 1957 because there is a time lag for the transfer of excess ${ }^{14} \mathrm{C}$ between the 2 hemispheres of the troposphere. Meanwhile, $\Delta^{14} \mathrm{C}$ values of the southern stratosphere increased slightly during 1957 (Figure 5). A similar situation was noted for 1961, when there was no increase in the amount of ${ }^{14} \mathrm{C}$ transferred from the Northern Hemisphere to the Southern Hemisphere (see Figure 4), and a slight increase of ${ }^{14} \mathrm{C}$ in the southern stratosphere (see Figure 5). These slight changes in the relative contributions of the 2 excess ${ }^{14} \mathrm{C}$ sources to the southern troposphere might explain the negative Armidale-Tasmania offsets at the ends of 1957 and 1961 (and perhaps also 1954, for which there are no data on stratospheric ${ }^{14} \mathrm{C}$; see Figure 5; Telegadas 1971; Hesshaimer and Levin 2000). 


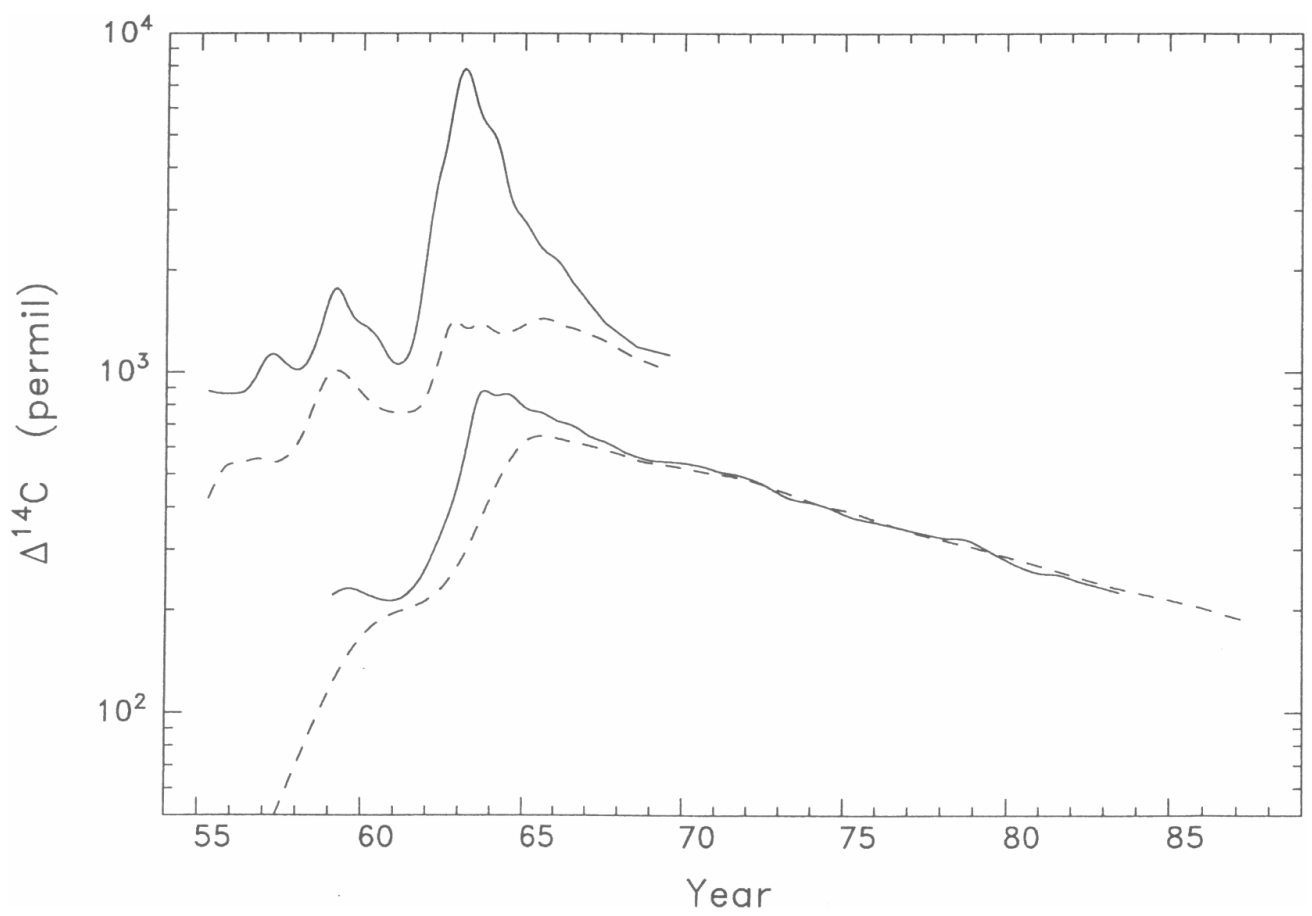

Figure $5 \Delta^{14} \mathrm{C}$ values in the stratosphere and troposphere for the bomb period (after Manning et al. 1990). The upper 2 curves are for the stratosphere and the lower 2 for the troposphere. The solid and dotted lines denote the Northern and Southern Hemisphere, respectively.

In contrast, during the steepest rise of bomb ${ }^{14} \mathrm{C}, \Delta{ }^{14} \mathrm{C}$ values for Armidale were slightly higher than those for Tasmania (at the ends of 1963, 1964, 1968, and 1969). It was clear that this steep rise of ${ }^{14} \mathrm{C}$ was due to high-yield nuclear weapon tests in 1961-1962 (Figure 4). These detonations injected a large amount of artificial ${ }^{14} \mathrm{C}$ into the upper and high stratosphere in the Northern Hemisphere. As a result, the major transport of excess ${ }^{14} \mathrm{C}$ was from the northern stratosphere to the northern troposphere then to the southern troposphere. During this period of time, the concentration of excess ${ }^{14} \mathrm{C}$ in the northern stratosphere was much higher than that in the southern stratosphere (Figure 5), so the amount of excess ${ }^{14} \mathrm{C}$ injected into the southern troposphere from the southern stratosphere would be smaller than that from the northern troposphere. This would explain why there were positive Armidale-Tasmania offsets for the steep rise of bomb ${ }^{14} \mathrm{C}$ (at the ends of 1963 and 1964). Bomb ${ }^{14} \mathrm{C}$ reached a maximum at the end of 1965, then decreased. There were no differences between Armidale and Tasmania at the ends of 1965, 1966, and 1967. However, there were positive Armidale-Tasmania offsets at the ends of 1968 and 1969. This might be due to some sporadic nuclear bomb tests in the Northern Hemisphere in 1967, 1968, and 1969.

In the decay of bomb ${ }^{14} \mathrm{C}$, there were some disturbances (Figure 6). A small peak in tree ring $\Delta^{14} \mathrm{C}$ was found in German pine in the middle of 1970. Levin et al. (1985) suggested that a nearby nuclear power plant caused this effect (see Table 6 of Levin et al. 1985). This $\Delta^{14} \mathrm{C}$ peak was also found in Hungarian tree rings in the middle of 1970 and in Thai tree rings in the middle of 1971 as the transport time of bomb ${ }^{14} \mathrm{C}$ from northern temperate region to the tropics is $\sim 1 \mathrm{yr}$ (Hua et al. 2000). These disturbances were also observed around 1970 in the atmospheric records for Fruholmen, Norway, at $71^{\circ} \mathrm{N}$ (Nydal and Lövseth 1983). These features indicate that the effect was not local or regional, but global, and that it was caused by sporadic atmospheric nuclear tests after 1963 performed by China in the Northern Hemisphere and France in the South Pacific (Enting 1982). A small bomb peak is 
expected to be found in the Southern Hemisphere temperate region at the end of 1971 as the transport time of bomb ${ }^{14} \mathrm{C}$ from the tropics to the southern temperate region is $\sim 0.5 \mathrm{yr}$ (Hua et al. 2000). However, as mentioned above, the ${ }^{14} \mathrm{C}$ excess becomes diffused when it is transported over the broad ITCZ; no small bomb peak was found in either the Armidale or the Tasmanian series at the end of 1971.

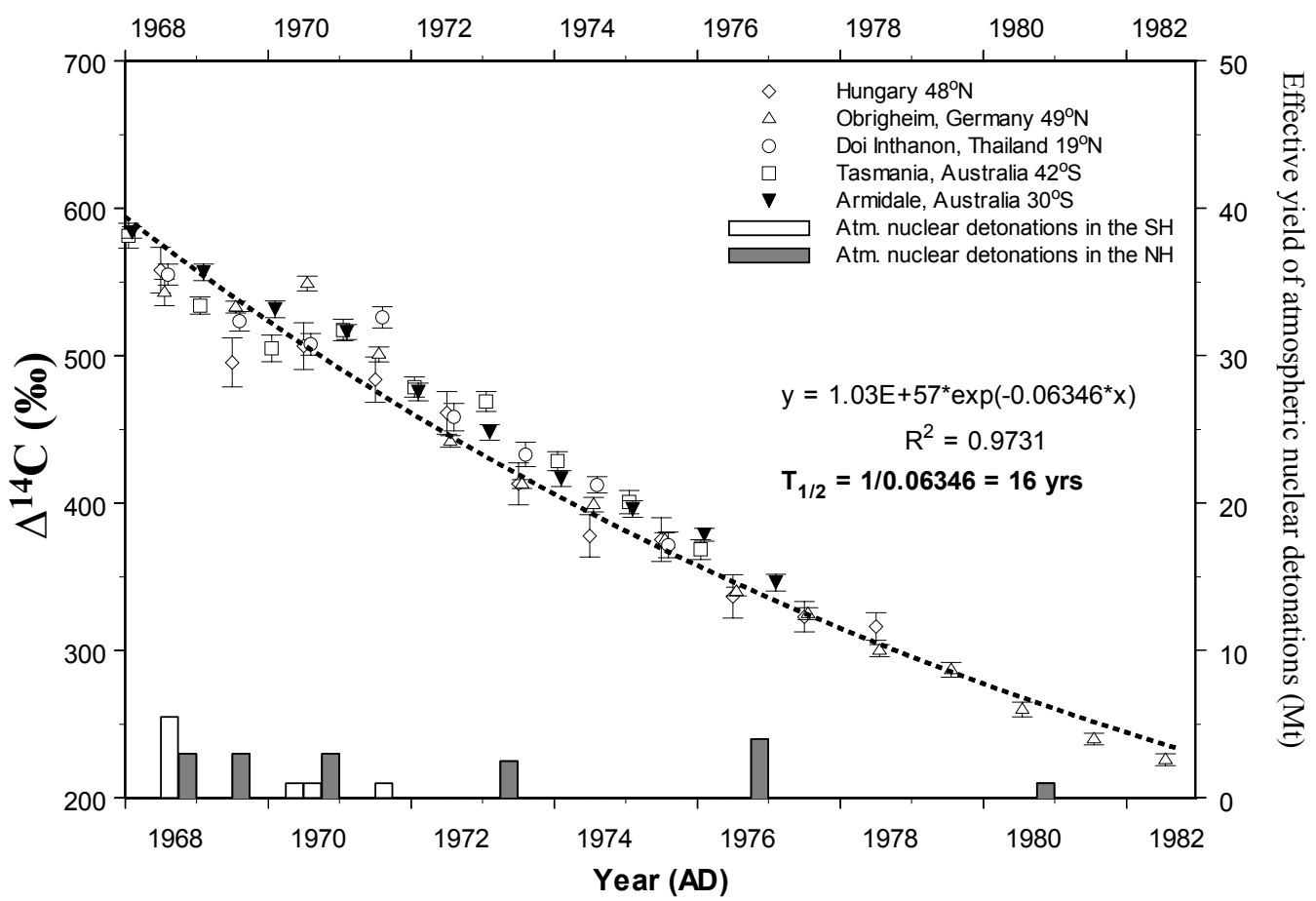

Figure 6 Influences of sporadic atmospheric nuclear tests after the 1963 Test Ban Treaty and decay of bomb ${ }^{14} \mathrm{C}$. Measured $\Delta{ }^{14} \mathrm{C}$ values for Armidale Pinus radiata are shown for the revised chronology (RC) only. Sources of $\Delta^{14} \mathrm{C}$ data for tree rings and effective yield of atmospheric nuclear detonations are shown in Figure 4.

There were small upward fluctuations in Tasmanian Huon pine at the ends of 1970 and 1972 and the $\Delta \Delta^{14} \mathrm{C}$ value for Tasmania was slightly higher than that for Armidale at the end of 1972 . These fluctuations might be due to atmospheric nuclear tests in the South Pacific in 1968 and 1970, and 1971, respectively (Figure 6). However, there were no significant fluctuations for Armidale Pinus radiata (except perhaps for a small upward fluctuation less pronounced than that for Tasmania at the end of 1970). As mentioned above, Tasmania is more sensitive to the injection from the southern stratosphere and, therefore, to atmospheric nuclear bomb tests in the Southern Hemisphere. As a consequence, Tasmania became equal to Armidale at the ends 1970 and 1971 (Tasmania was lower than Armidale at the end of 1969, as mentioned previously), and was slightly higher than Armidale at the end of 1972. This would also explain why no pronounced fluctuations in atmospheric ${ }^{14} \mathrm{C}$ between 1970-1976 were found in Armidale tree rings.

Most of the Armidale-Tasmania offsets discussed above (negative at the ends of 1954, 1957, 1961 and 1972; positive at the ends of 1964, 1968, and 1969) were small, as the 2 data sets did not overlap within $1 \sigma$ error but did overlap within $2 \sigma$ error. Only one significant offset, where the 2 data sets did not overlap within $2 \sigma$ error, was found at the end of 1963. This significant difference between Armidale and Tasmania might be due to large amount of excess ${ }^{14} \mathrm{C}$ transferred from the Northern to Southern Hemisphere during the steep rise of bomb ${ }^{14} \mathrm{C}$ at the end of 1963 . 
Although there were some small disturbances between $1970-1972$, bomb ${ }^{14} \mathrm{C}$ reached a global equilibrium at the end of 1968 (Telegadas 1971) and decreased exponentially, halving every 16 yr (Figure 6). This estimate is very similar to those of previous work: $17 \mathrm{yr}$ from Manning et al. (1990) and Dai et al. (1992), $18 \mathrm{yr}$ (inversion of a decay constant of $0.055 \mathrm{yr}^{-1}$ ) from Nydal and Gislefoss (1996), and 16 yr from Levin and Kromer (1997) and Park et al. (2002).

\section{AIR-SEA EXCHANGE OF $\mathrm{CO}_{2}$ FOR SOUTHERN PACIFIC MID-LATITUDES}

Measured $\Delta^{14} \mathrm{C}$ values for Armidale tree rings and those for corals from the Great Barrier Reef are shown in Figure 7. The coral $\Delta^{14} \mathrm{C}$ were the average values of 3 different sites: Heron Island $\left(23^{\circ} \mathrm{S}\right.$, $\left.152^{\circ} \mathrm{E}\right)$, Abraham Reef $\left(22^{\circ} \mathrm{S}, 153^{\circ} \mathrm{E}\right)$, and Lady Musgrave Island $\left(24^{\circ} \mathrm{S}, 153^{\circ} \mathrm{E}\right)$ (Druffel and Griffin 1995). Atmospheric $\Delta^{14} \mathrm{C}$ for Armidale increased from -22\%o at the beginning of 1955 to $186.8 \%$ at the beginning of 1960 . As a result of the transfer of bomb ${ }^{14} \mathrm{C}$ from the atmosphere to the surface ocean, $\Delta^{14} \mathrm{C}$ in Great Barrier Reef corals slightly increased from $-54.7 \%$ in early 1955 to $-22.8 \%$ o in early 1961 . Then, atmospheric $\Delta{ }^{14} \mathrm{C}$ dramatically increased from $191.2 \%$ at the beginning of 1962 to a maximum level of $628.2 \%$ at the beginning of 1966 due to the high level of atmospheric nuclear detonations in 1961-1962 (Figure 4). The $\Delta \Delta^{14} \mathrm{C}$ level in corals increased from -29.2\%o in early 1962 to $95.5 \%$ in early 1968 . This period saw a steep rise of bomb ${ }^{14} \mathrm{C}$ in the surface ocean of the Great Barrier Reef. After 1966, although atmospheric $\Delta{ }^{14} \mathrm{C}$ decreased, the $\Delta{ }^{14} \mathrm{C}$ level in Great Barrier Reef corals still increased with a lower rate and reached a maximum of about 141\%o between 1976-1980. This occurred because there was a large amount of excess ${ }^{14} \mathrm{C}$ in the atmosphere after the major bomb tests which was still being transferred to the oceans. After 1980 , the $\Delta{ }^{14} \mathrm{C}$ level in the surface ocean of the Great Barrier Reef decreased.

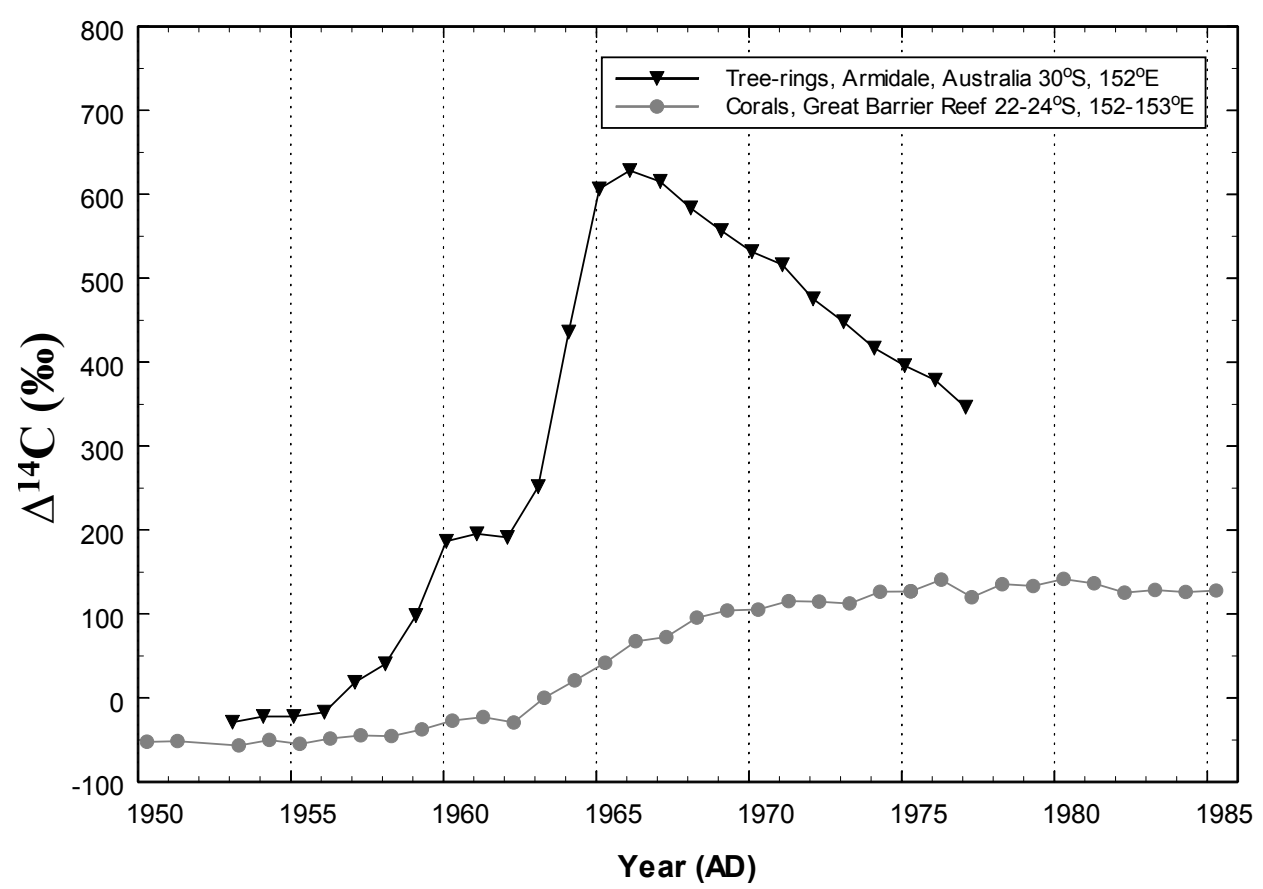

Figure $7{ }^{14} \mathrm{C}$ in tree rings compared with that in corals for southern mid-latitudes. Measured $\Delta^{14} \mathrm{C}$ values for Armidale Pinus radiata are shown for the revised chronology (RC) only. $\Delta^{14} \mathrm{C}$ values for corals are the average values of 3 different sites (Heron Island, Abraham Reef, and Lady Musgrave Island) from the Great Barrier Reef (Druffel and Griffin 1995). Error bars are too small to be shown. 
We have used a 1D box model to estimate the time for air-sea exchange of $\mathrm{CO}_{2}$ for the mid-southern Pacific, with the assumption that only vertical transport in the oceans was responsible for the transfer of bomb ${ }^{14} \mathrm{C}$ from the atmosphere to the oceans. The model consisted of a box diffusion ocean from Oeschger et al. (1975), including a homogenous surface-mixed layer of $75 \mathrm{~m}$, and deep sea water divided into 36 boxes of $25 \mathrm{~m}$ and 5 boxes of $560 \mathrm{~m}$. The transfer of ${ }^{14} \mathrm{CO}_{2}$ between the surfacemixed layer and deep sea water was parameterized by a constant vertical eddy diffusivity $K$. The transfer of bomb ${ }^{14} \mathrm{C}$ from the atmosphere to the surface-mixed layer was parameterized by a constant exchange coefficient $\mathrm{k}_{\mathrm{am}}$, which is inversely proportional to the time for the air-sea exchange $\tau_{\mathrm{am}}$. If the time history of atmospheric ${ }^{14} \mathrm{C}$ (the source of bomb ${ }^{14} \mathrm{C}$ for the oceans) and the constant eddy $K$ are known, one can estimate the air-sea exchange coefficient $\mathrm{k}_{\mathrm{am}}$ for a particular region using the above model.

The source function of bomb ${ }^{14} \mathrm{C}$ in the atmosphere was our measured $\Delta^{14} \mathrm{C}$ data from Armidale tree rings (1953-1977). Because atmospheric $\mathrm{CO}_{2}$ content was not constant but increased significantly (Etheridge et al. 1998) during the period of our study (the bomb pulse period), we had to include the ${ }^{12} \mathrm{C}$ species in our modelling. The source function of atmospheric $\mathrm{CO}_{2}$ was the measured $\mathrm{CO}_{2}$ data from Law Dome DE08 and DE08-2 ice cores from Antarctica (AD 1832-1977, Etheridge et al. $1998)$. The eddy diffusivity $K$ for the ocean close to the Great Barrier Reef corals $\left(22-24^{\circ} \mathrm{S}, 152\right.$ $\left.153^{\circ} \mathrm{E}\right)$ was determined from GEOSECS Tritium data of Pacific stations $269\left(23^{\circ} 57^{\prime} \mathrm{S}, 174^{\circ} 31^{\prime} \mathrm{W}\right)$ and $310\left(26^{\circ} 57^{\prime} \mathrm{S}, 157^{\circ} 9^{\prime} \mathrm{W}\right)$ (see Figure 8 for locations of Armidale tree rings, corals from the Great Barrier Reef, and the 2 GEOSECS Pacific stations). The mean depth of tritium penetration in 1973 for the 2 stations was $360 \mathrm{~m}$ ( $370 \mathrm{~m}$ for station 269 and $350 \mathrm{~m}$ for station 310, Broecker et al. 1980), which was equivalent to an eddy diffusivity $K$ of $4890 \mathrm{~m}^{-2} \mathrm{y}^{-1}$ (Broecker et al. 1980). The average pre-bomb $\Delta^{14} \mathrm{C}$ value of Great Barrier Reef corals was about $-50 \%$ o $(-49.6 \pm 3.6 \%$ for Abraham Reef for $1800-1957$, Druffel and Griffin $1993 ;-49.8 \pm 3.8 \%$ for Heron Island for $1849-1955$, Druffel and Griffin 1999). The model was run from 1832 to 1977 and the initial $\Delta^{14} \mathrm{C}$ value of the surface-mixed layer was chosen so that the average pre-bomb $\Delta^{14} \mathrm{C}$ value of the surface waters for 1832-1955 calculated from the model was in agreement with that of the Great Barrier Reef corals of $-50 \%$.

The model was then run with different values of $\mathrm{k}_{\mathrm{am}}$. The best $\mathrm{k}_{\mathrm{am}}$ was determined when there was the best fit to the measured $\Delta^{14} \mathrm{C}$ for the mixed layer $\left(\Delta^{14} \mathrm{C}\right.$ values from the Great Barrier Reef corals for 1953-1977, Druffel and Griffin 1995) and the measured $\Delta^{14} \mathrm{C}$ for the deep ocean close to the Great Barrier Reef $\left(\Delta^{14} \mathrm{C}\right.$ values of deep ocean for stations 269 and 310 in 1974, Östlund and Stuiver 1980). The air-sea exchange coefficient $k_{\text {am }}$ for mid-southern Pacific estimated by the model was $1 /$ $7.5 \mathrm{yr}^{-1}$, which was equivalent to a $\tau_{\mathrm{am}}$ of $7.5 \mathrm{yr}$. Figures 9 and 10 show $\Delta^{14} \mathrm{C}$ values calculated by the model versus experimental $\Delta^{14} \mathrm{C}$ data for the surface-mixed layer and deep ocean for the best estimated value of $\mathrm{k}_{\mathrm{am}}$ of $1 / 7.5 \mathrm{yr}^{-1}$, respectively. A good agreement between measured $\Delta^{14} \mathrm{C}$ data for surface ocean derived from corals and those calculated from the model was found (Figure 9). However, for the deep ocean the agreement between experimental ${ }^{14} \mathrm{C}$ data and those determined from the model were not very good for the depth between 100-600 m (Figure 10). This suggested that using only vertical transport (diffusion) in the oceans does not properly explain the transfer of bomb ${ }^{14} \mathrm{C}$ to the deep sea for the mid-southern Pacific Ocean.

The corresponding flux of $\mathrm{CO}_{2}\left(\mathrm{k}_{\mathrm{am}}\right.$ of $\left.1 / 7.5 \mathrm{yr}^{-1}\right)$ from the atmosphere to the surface ocean for midsouthern Pacific for the $1970 \mathrm{~s}\left(\mathrm{CO}_{2}\right.$ mixing ratio of $330 \mathrm{ppm}$, Etheridge et al. 1998) was 21.5 moles $\mathrm{m}^{-2} \mathrm{y}^{-1}$. Our estimated value is in agreement with the estimate of 22 moles $\mathrm{m}^{-2} \mathrm{y}^{-1}$ for the $\mathrm{CO}_{2}$ invasion rate for the south temperate region of the Pacific by Broecker et al. (1985). Quay and Stuiver (1980) determined the $\mathrm{CO}_{2}$ gas exchange for the mid-southern Pacific. Their average value of $\mathrm{CO}_{2}$ 


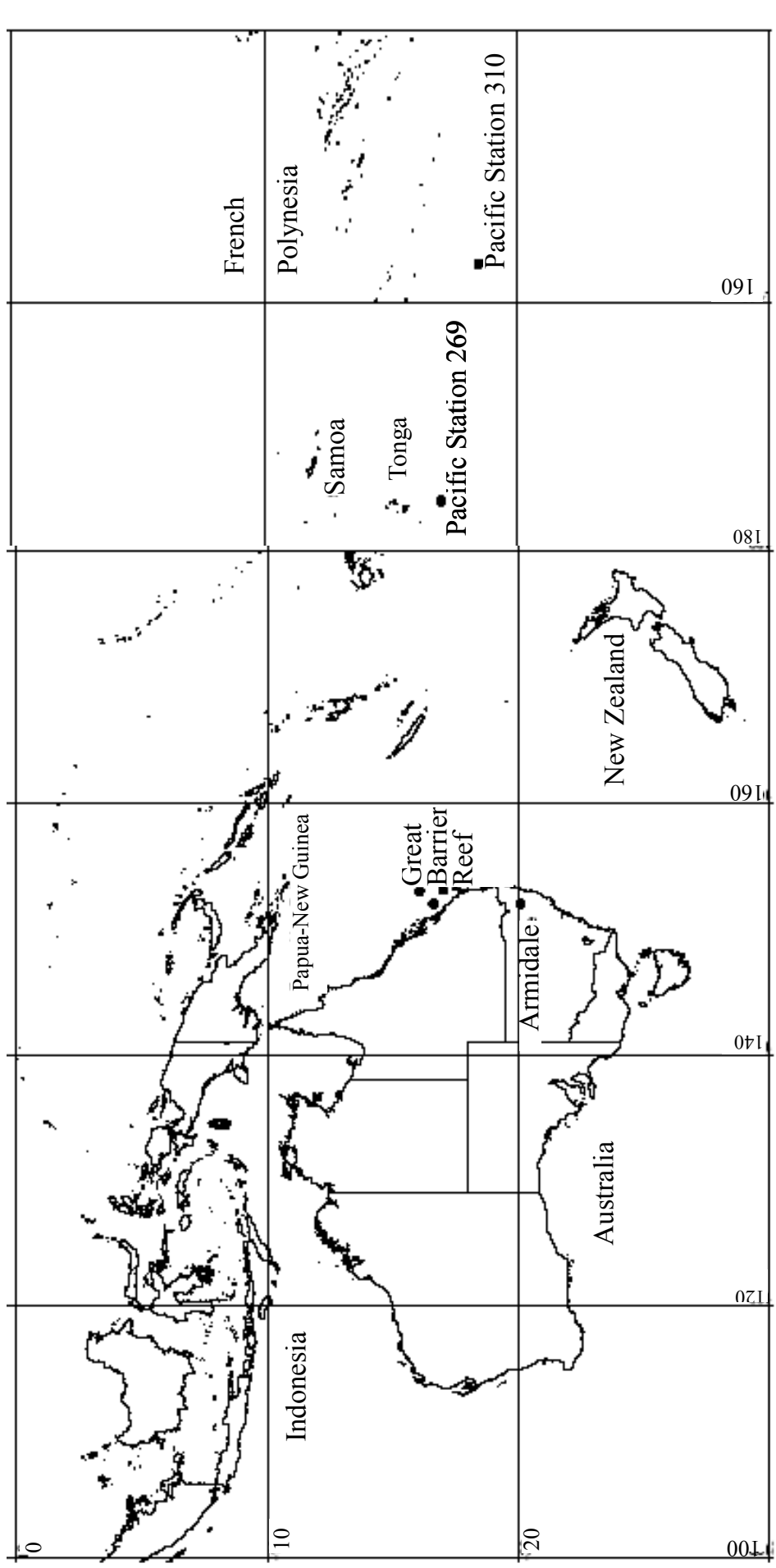

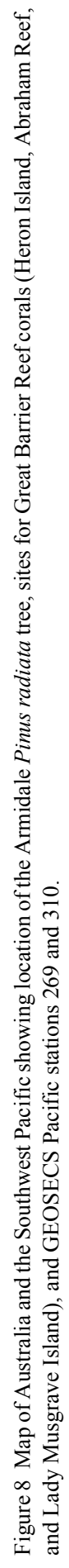




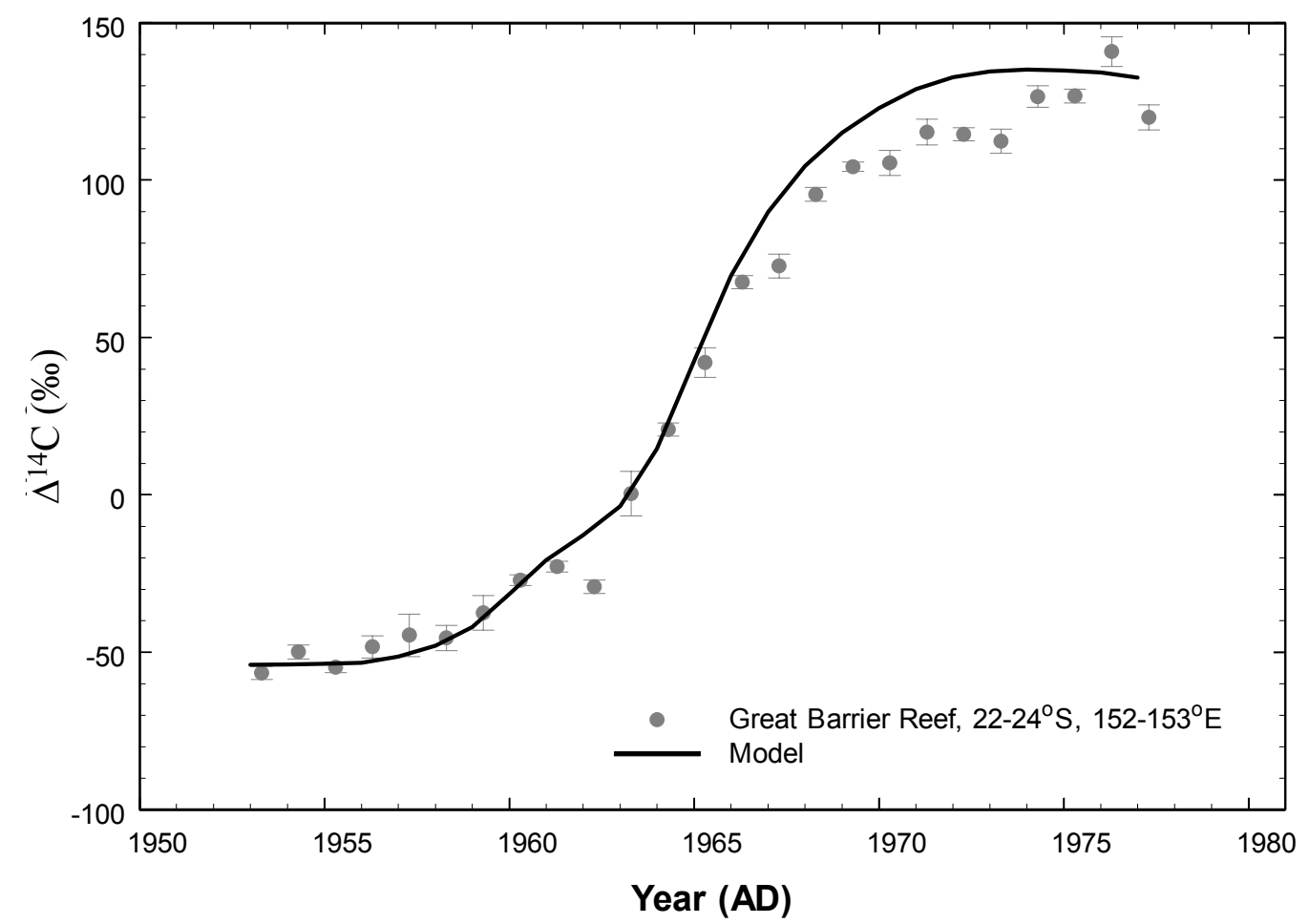

Figure $9 \Delta^{14} \mathrm{C}$ in corals from the Great Barrier Reef (average values of corals from 3 different sites as in Figure 7) compared to that calculated from the model for the case of best estimate $\mathrm{k}_{\mathrm{am}}$ of $1 / 7.5 \mathrm{yr}^{-1}$.

gas exchange from 4 stations $(322,320,317$, and 324$)$ located east of $150^{\circ} \mathrm{W}$ was $25 \mathrm{moles} \mathrm{m}^{-2} \mathrm{y}^{-1}$. Stuiver et al. (1981) estimated the average air-sea exchange rate of $26.5 \mathrm{moles} \mathrm{m}^{-2} \mathrm{y}^{-1}$ for the south Pacific from $10^{\circ} \mathrm{S}$ to $50^{\circ} \mathrm{S}$. Our estimate is slightly lower than those from Quay and Stuiver (1980) and Stuiver et al. (1981). The difference between the 3 estimates might be due to the difference in study areas: $23-27^{\circ} \mathrm{S}, 152^{\circ} \mathrm{E}-158^{\circ} \mathrm{W}$ (this study); $23-43^{\circ} \mathrm{S}, 128-146^{\circ} \mathrm{W}$ (Quay and Stuiver 1980); south Pacific between $10-50^{\circ} \mathrm{S}$ (Stuiver et al. 1981).

\section{CONCLUSION}

This is the first time that a site in inland Australia has been used to examine the rise in atmospheric ${ }^{14} \mathrm{C}$ due to atmospheric nuclear detonations in the late 1950s and early 1960s. Our AMS ${ }^{14} \mathrm{C}$ results for single tree rings from Armidale $30^{\circ} \mathrm{S}$ (Australia, rings 1952-1976) revealed some interesting features of Southern Hemisphere bomb ${ }^{14} \mathrm{C}$ and their implications for global atmospheric circulation. On average, the difference between Armidale and Tasmania in terms of ${ }^{14} \mathrm{C}$ was negligible, implying a small latitudinal gradient for the Southern Hemisphere. This situation contrasts with that of the Northern Hemisphere, where there was a large latitudinal gradient of ${ }^{14} \mathrm{C}$ during the bomb peak. However, small offset variations between Armidale and Tasmania were observed. This might suggest some indications about relative contributions of the 2 excess ${ }^{14} \mathrm{C}$ sources (the northern troposphere and southern stratosphere) to the southern troposphere. Together with previously published ${ }^{14} \mathrm{C}$ data from tree rings, ${ }^{14} \mathrm{C}$ in Armidale Pinus radiata decreased exponentially, halving every $16 \mathrm{yr}$. 


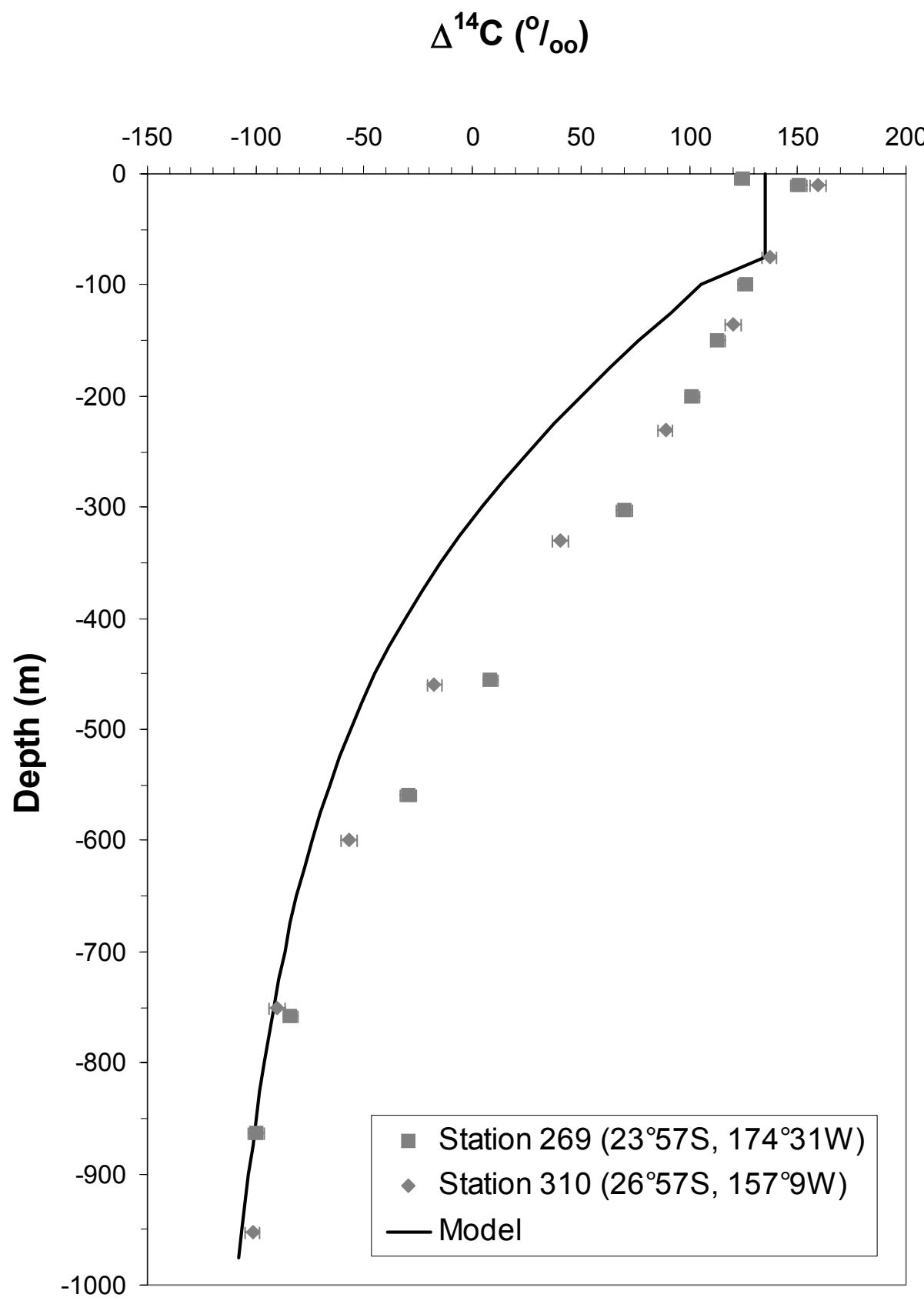

Figure 10 Oceanic $\Delta^{14} \mathrm{C}$ for stations 269 and 310 in the South Pacific (values respectively for January and April 1974 during the GEOSECS expedition, Östlund and Stuiver 1980) compared to that calculated from the model for the case of the best estimate $\mathrm{k}_{\mathrm{am}}$ of $1 / 7.5 \mathrm{yr}^{-1}$. The penetration of bomb ${ }^{14} \mathrm{C}$ in the Pacific Ocean at the time of GEOSECS expedition in 1974 was less than $1000 \mathrm{~m}$ (Broecker et al. 1985); therefore, only oceanic ${ }^{14} \mathrm{C}$ data from depths less than $1000 \mathrm{~m}$ were used for comparison. 
By using our measured ${ }^{14} \mathrm{C}$ from Armidale Pinus radiata together with previously published ${ }^{14} \mathrm{C}$ data from Great Barrier Reef corals (Druffel and Griffin 1995) and from 2 GEOSECS southwest Pacific stations (269 and 310, Östlund and Stuiver 1980), we estimated the time for air-sea exchange of $\mathrm{CO}_{2}$ of $\sim 7.5 \mathrm{yr}$ for the mid-southern Pacific, which was equivalent to a $\mathrm{CO}_{2}$ flux from the atmosphere to the surface ocean of 21.5 moles $\mathrm{m}^{-2} \mathrm{y}^{-1}$ for the 1970s. The results also showed that bomb ${ }^{14} \mathrm{C}$ is a very useful tool to complement the standard techniques of dendrochronology in detecting misidentified rings when tree rings are analyzed by ${ }^{14} \mathrm{C}$ in a way similar to our experiment-a series of consecutive annual rings during the bomb pulse period.

\section{ACKNOWLEDGEMENTS}

The authors wish to thank Tom Joyce (Electron Microscope Unit, University of Sydney) for photos of Pinus radiata DFR 021, and other members of the AMS Project (ANSTO) for helping with sample preparation and ${ }^{14} \mathrm{C}$ measurement. Dr Peter Grave of University of New England encouraged one of us (MB) to begin sampling of Pinus radiata and other trees in the Armidale region. Mrs A M Macintosh has provided generous financial support for the NWG Macintosh Centre since 1982. We gratefully acknowledge funding from the Australian Institute of Nuclear Science and Engineering (AINSE) for AMS ${ }^{14} \mathrm{C}$ measurements (grants 98/162R and 02/165).

\section{REFERENCES}

Broecker WS, Peng TH, Engh R. 1980. Modelling the carbon system. Radiocarbon 22(3):565-98.

Broecker WS, Peng TH, Östlund G, Stuiver M. 1985. The distribution of bomb radiocarbon in the ocean. Journal of Geophysical Research 90:6953-70.

Bureau of Meteorology. 1999. Monthly rainfall data for Armidale, 1920-1997. Melbourne.

Cain WF, Suess HE. 1976. Carbon 14 in tree rings. Journal of Geophysical Research 81:3688-94.

Dai K, Qian Y, Fan CY. 1992. Bomb-produced ${ }^{14} \mathrm{C}$ in tree rings. Radiocarbon 34(3):753-6.

Druffel ERM, Griffin S. 1993. Large variations of surface ocean radiocarbon: evidence of circulation changes in the southwestern Pacific. Journal of Geophysical Research 98(C11):20,249-59.

Druffel ERM, Griffin S. 1995. Regional variability of surface ocean radiocarbon from Southern Great Barrier Reef corals. Radiocarbon 37(2):517-24.

Druffel ERM, Griffin S. 1999. Variability of surface radiocarbon and stable isotopes in the southwestern $\mathrm{Pa}$ cific. Journal of Geophysical Research 104(C10): 23,607-13.

Druffel EM, Suess HE. 1983. On the radiocarbon record in banded corals: exchange parameters and net transport of ${ }^{14} \mathrm{CO}_{2}$ between atmosphere and surface ocean. Journal of Geophysical Research 88(C2):1271-80.

Enting IG. 1982. Nuclear weapons data for use in carbon cycle modelling. CSIRO Division of Atmospheric Physics Technical Paper No. 44. Melbourne: CSIRO.

Etheridge DM, Steele LP, Langenfels RL, Francey RJ, Barnola JM, Morgan VI. 1998. Historical $\mathrm{CO}_{2}$ records from the Law Dome DE08, DE08-2 and DSS ice cores. In: Trends: A Compendium of Data on Global Change. Carbon Dioxide Information Analysis Cen- ter, Oak Ridge National Laboratory, US Department of Energy, Oak Ridge, Tennessee, USA. URL: http:// cdiac.esd.ornl.gov.trends/co2/lawdome.html.

Fink D, Hotchkis MAC, Hua Q, Jacobsen GE, Smith AM, Zoppi U, Child D, Mifsud C, van der Gaast HA, Williams AA, Williams M. 2003. Forthcoming. The ANTARES AMS Facility at ANSTO. Nuclear Instruments and Methods in Physics Research B.

Hertelendi E, Csongor E. 1982. Anthropogenic ${ }^{14} \mathrm{C}$ excess in the troposphere between 1951 and 1978 measured in tree rings. Radiochemical and Radioanalytical Letters 56(2):103-10.

Hesshaimer V, Levin I. 2000. Revision of the stratospheric bomb ${ }^{14} \mathrm{CO}_{2}$ inventory. Journal of Geophysical Research 105(D9):11,641-58.

Hua Q, Barbetti M. Forthcoming. Compilation of tropospheric bomb ${ }^{14} \mathrm{C}$ data for carbon cycle modelling and age calibration purposes. Radiocarbon.

Hua Q, Barbetti M, Worbes M, Head J, Levchenko VA. 1999. Review of radiocarbon data from atmospheric and tree ring samples for the period AD 1945-1997. IAWA Journal 20(3):261-83.

Hua Q, Barbetti M, Jacobsen GE, Zoppi U, Lawson EM. 2000. Bomb radiocarbon in annual tree rings from Thailand and Tasmania. Nuclear Instruments and Methods in Physics Research B 172:359-65.

Hua Q, Jacobsen GE, Zoppi U, Lawson EM, Williams AA, Smith AM, McGann MJ. 2001. Progress in radiocarbon target preparation at the ANTARES AMS Centre. Radiocarbon 43(2A):275-82.

Lawson EM, Elliott G, Fallon J, Fink D, Hotchkis MAC, Hua Q, Jacobsen GE, Lee P, Smith AM, Tuniz C, Zoppi U. 2000. AMS at ANTARES-The first 10 years. Nuclear Instruments and Methods in Physics 
Research B 172:95-9.

Levin I, Hesshaimer V. 2000. Radiocarbon-A unique tracer of global carbon cycle dynamics. Radiocarbon 42(1):69-80.

Levin I, Kromer B. 1997. Twenty years of atmospheric ${ }^{14} \mathrm{CO}_{2}$ observations at Schauinsland station, Germany. Radiocarbon 39(2):205-18.

Levin I, Kromer B, Schoch-Fischer H, Bruns M, Munnich M, Berdau D, Vogel JC, Munnich KO. 1985. Twenty-five years of tropospheric ${ }^{14} \mathrm{C}$ observations in Central Europe. Radiocarbon 27(1):1-19.

Linacre E, Geerts B. 1997. Climates and Weather Explained. London: Routledge.

Manning MR, Melhuish WH. 1994. $\Delta^{14} \mathrm{CO}_{2}$ record from Wellington. In: Trends: A compendium of data on global change. Carbon Dioxide Information Analysis Center, Oak Ridge National Laboratory, US Department of Energy, Oak Ridge, Tennesse, USA. URL: http://cdiac.esd.ornl.gov.trends/co2/welling.html.

Manning MR, Lowe DC, Melhuish WH, Sparks RJ, Wallace G, Brenninkmeijer CAM, McGrill RC. 1990. The use of radiocarbon measurements in atmospheric studies. Radiocarbon 32(1):37-58.

Meijer HAJ, van der Plicht J, Gislefoss JS, Nydal R. 1995. Comparing long-term atmospheric ${ }^{14} \mathrm{C}$ and ${ }^{3} \mathrm{H}$ records near Groningen, the Netherlands with Fruholmen, Norway and Izaña, Canary Islands ${ }^{14} \mathrm{C}$ stations. Radiocarbon 37(1):39-50.

Muraki Y, Korachov G, Nishiyama T, Naruse Y, Murata T, Masuda K, Arslanov KhA. 1998. The new Nagoya radiocarbon laboratory. Radiocarbon 40(1):177-82.

Nydal R. 1968. Further investigation on the transfer of radiocarbon in nature. Journal of Geophysical Research 73(12):3617-35.
Nydal R, Gislefoss JS. 1996. Further application of bomb ${ }^{14} \mathrm{C}$ as a tracer in the atmosphere and ocean. Radiocarbon 38(3):389-406.

Nydal R, Lövseth K. 1983. Tracing bomb ${ }^{14} \mathrm{C}$ in the atmosphere 1962-1980. Journal of Geophysical Research 88(C6): 3621-42.

Oeschger H, Siegenthaler U, Schotterer U, Gugelmann A. 1975. A box diffusion model to study the carbon dioxide exchange in nature. Tellus 27(2):168-92.

Östlund HG, Stuiver M. 1980. GEOSECS Pacific Radiocarbon. Radiocarbon 22(1):25-53.

Park JH, Kim JC, Cheoun MK, Kim IC, Youn M, Liu YH, Kim ES. 2002. ${ }^{14} \mathrm{C}$ Level at Mt Chiak and Mt Kyeryong in Korea. Radiocarbon 44(2):559-66.

Quay PD, Stuiver M. 1980. Vertical advection-Diffusion rates in the oceanic thermocline determined from ${ }^{14} \mathrm{C}$ distributions. Radiocarbon 22(3):607-25.

Stuiver M, Polach HA. 1977. Reporting of ${ }^{14} \mathrm{C}$ data. $R a-$ diocarbon 19(3):353-63.

Stuiver M, Östlund HG, McConnaughey TA. 1981. GEOSECS Atlantic and Pacific ${ }^{14} \mathrm{C}$ distribution. In: Bolin B, editor. Carbon Cycle Modelling (Scope 16). New York: John Wiley \& Sons. p 201-21.

Telegadas K. 1971. The seasonal atmospheric distribution and inventories of excess carbon-14 from March 1955 to July 1969. US Atomic Energy Commission Report HASL-243.

Vogel JC, Marais M. 1971. Pretoria radiocarbon dates I. Radiocarbon 13(2):378-94, and regular updates.

Yang X, North R, Rommey C. 2000. CMR Nuclear Explosion Database (revision 3). CMR Technical Report CMR-00/16. Center for Monitoring Research, Arlington, Virginia, USA. URL: http://www.pidc.org/rdss/ nucex/report/explosion.pdf. 